eISSN: 2398-4287 @ 2016. The Authors. Published for AMER ABRA cE-Bs by e-International Publishing House, Ltd., UK. This is an open access journal under the CC BYNC-ND license (http://creativecommons.org/licenses/by-nc-nd/4.0/). Peer-review under responsibility of AMER (Association of Malaysian Environment-Behaviour Researchers), ABRA (Association of Behavioural Researchers on Asians) and cE-Bs (Centre for Environment-Behaviour Studies), Faculty of Architecture, Planning \& Surveying, Universiti Teknologi MARA, Malaysia.

DOI: https://doi.org/10.21834/e-bpj.v1i4

e-mail: cebsuitm@gmail.com Cataloguing-in-Publication Data

7th Asia Pacific International Conference on Environment-Behaviour Studies, AicE-Bs2016 (2016: Edinburgh. UK)

Proceeding, 7th Asia Pacific International Conference on Environment-Behaviour Studies The University of Edinburgh, UK, 27-30 July 2016 editors: Mohamed Yusoff Abbas, Sharifah Khalizah Syed Othman Thani

1.Environment-Behaviour-Asia Pacific Area--Congresses.

2. Environmental Psychology-- Asia Pacific Area--Congresses.

I. Mohamed Yusoff Abbas, Sharifah Khalizah Syed Othman Thani. Title. Cover design: emAs

Typeface : Ariel Narrow, Times New Roman Typesize : 8/10/11/12/14/16/18/26/28

Published by e-IPH Ltd., United Kingdom @

e-International Publishing House, Limited

(Registration No: 10062603, for England \& Wales)

PO Box Studio 7, The Leadmill, 6 Leadmill Road, Sheffield S1 4SE, United Kingdom.

Tel: 00447446 100896; Email: admin@e-iph.co.uk Web: https://www.e-iph.co.uk

elSSN: 2398-4287

20 September 2016 




\section{Environment - Behaviour Proceedings Journal}

\section{AicE-Bs2016Edinburgh $7^{\text {th }}$ Asia Pacific International Conference on Environment-Behaviour Studies \\ The University of Edinburgh, UK \\ 27-30 July 2016}

Editors

Mohamed Yusoff Abbas

Sharifah Khalizah Syed Othman Thani

Associate Editors:

EGYPT: Rasha Mahmoud Ali El-Zeiny

INDIA: Smita Khan

INDONESIA: Juneman Abraham

IRAN: Mona Bisadi

TAIWAN: Shenglin Elijah Chang

TURKEY: Ebru Cubukcu

Available Online at www.e-iph.co.uk AMER 且 ABRA cE-Bs

Indexed in: 


\section{Acknowledgement}

This 7th Asia Pacific International Conference on Environment-Behaviour Studies, AicEBs2016Edinburgh, was made possible by many persons.

Deepest appreciation to our Co-Host, the Edinburgh School of Architecture and Landscape Architecture, Edinburgh College of Art, The University of Edinburgh, UK. which facilitated the smooth running and success of the conference.

Many thanks also to the more than 60 International Scientific Committee (ISC) / ajE-Bs \& jABs Editorial Board Members, represented from 22 countries worldwide, for their continuous commitment and dedication for reviewing the conference papers.

Last but not least, our gratitude to the Distinguished Keynote Speakers, Abstract Contributors and Paper Presenters for disseminating their works and findings at this most memorable conference. Their continuous support in participation endorses the relevance and sustenance of more successful forthcoming conferences.

Thank you all ! 


\title{
Organising Committee
}

\author{
Mohamed Yusoff Abbas, Prof., Dr. \\ Chair, AicE-Bs2016 \\ President, AMER (Association of Malaysian Environment-Behaviour Researchers) \\ President, ABRA (Association of Behavioural Reserachers on Asians) \\ Head, cE-Bs, Faculty of Architecture, Planning \& Surveying, UiTM, Malaysia
}

Fiona McLachlan, Prof., Co-Chair, AcE-Bs2016

Edinburgh School of Architecture and Landscape Architecture, Edinburgh College of Art, The University of Edinburgh, Edinburgh, United Kingdom

\section{Co-Host Organising Committee}

Nik Farhanah Nik Azhari

\section{Conference Secretariat}

AMER Event Management \& Services (emAs)

Sharifah Khalizah Syed Othman Thani

Diyanah Inani Azmi

Maimunah Ramlee

Mohd Fauzee Musa

Mohd Riduan Ngesan

Roslinda Ghazali

Sabrina Aidilfitri

Suhaini Mohamed Yusoff

Siti Nur Afiqah Mohamed Musthafa

Syazwani Abd Kadir 


\section{Table of Contents}

Acknowledgement $\boldsymbol{v}$

Organising Committee vi

Table of Contents vii

Foreword ix

About the Conference $\boldsymbol{x}$

Editorial Team $\mathbf{x i}$

Full Paper List xiii

Past and Forthcoming Conferences 9 


\section{Foreword}

The AicE-Bs2016Edinburgh with "Adapted and adaptable environments" as the main theme managed to attract an overall total of 54 numbers of approved abstracts, from nine countries

Majority of the abstracts (35) were contributed by Malaysia. This was followed by Indonesia (6), Turkey (5), Egypt and Iran (2 each), and 1 each from China, Nigeria, Thailand and USA.The abstracts approved were simply grouped generally under 16 sub-categories, although quite a number could have been easily placed under more than one category. The top five categories in order of popularity involved the following environments:- Urban Environment / Urban Psychology (10), Local Heritage Environment (7), Educational / Learning Environment and Working Environment (6 each), and Community Environment / Social Psychology (4).

The Association of Malaysian Environment-Behaviour Researchers (AMER), the main organiser of AicE-Bs2016, together with the Co-Chair / Co-Host, the Edinburgh School of Architecture and Landscape Architecture, Edinburgh College of Art, The University of Edinburgh, UK., congratulate all contributors for making the conference a tremendous success!

Hopefully this conference will inspire and encourage more researchers to participate in our forthcoming serial conferences.

Thanks again for your continuous support as always, and hope for an enlightening conference!

\section{Prof. Dr. Mohamed Yusoff Abbas}

Chair, AicE-Bs2016Edinburgh

President, Association of Malaysian Environment-Behaviour Researchers (AMER), 2012-2018.

President, Association of Behavioural Researchers on Asians (ABRA), since 2014.

Head, Centre for Environment-Behaviour Studies (cE-Bs), Faculty of Architecture, Planning and Surveying (FAPS), Universiti Teknologi MARA (UiTM), Malaysia

http://www.amerabra.org/

cebsuitm@gmail.com

27th July 2016 


\section{About the Conference}

\section{Background}

The M1iCEBS (Malaysia's 1st International Conference on Environment-Behaviour Studies) officially soft-launched by Malaysian Director General, Womens Development Department, Ministry of Women, Family and Community Development during 1nCEBS (14-15 November 2009) had been renamed the ASIA Pacific International Conference on EnvironmentBehaviour Studies (AicE-Bs). AicE-Bs conference themes address Environment-Behaviour issues affecting the Asia/Pacific region. In particular, on issues affecting the Asian communities living in both Asian and non-Asian countries.

Prior to 2014, AicE-Bs were organized annually by cE-Bs (Centre for Environment-Behaviour Studies, FAPS, UiTM, Malaysia) in collaboration with ABRA (Association of Behavioural Researchers on Asians) / AMER (Association of Malaysian Environment-Behaviour Researchers) and non-ASEAN ajE-Bs / jABs Editorial Board member's establishment (as the National Conference, renamed Asian Conference on Environment-Behaviour Studies - AcE-Bs shall be held in Asian members' countries). Venues for AicE-Bs shall be determined by the willingness of any non-Asian ajE-Bs / jABs Editorial Board member's establishment to co-host the event. Post 2014, all conferences shall be organized by AMER and managed by emAs (AMER Event Management Services), under emAs emAs Resources.

Prior to 2015 all AcE-Bs and AicE-Bs Proceedings were published and accessible online in Elsevier's Procedia Social and Behavioural Sciences in www.ScienceDirect.com, which were also indexed in Thomsom Reuters (TR) CPCl, in their Web of Science (WoS). In view that Elsevier's Procedia Social and Behavioural Sciences ceased publication from late 2015 (apart from the final AicQoL2016 proceeding), under initiative by emAs, future proceedings shall be published by the e-IPH (International Publishing House), Ltd.,UK, the international associate of emAs. The e-IPH shall submit all proceedings to TR for indexing in their WoS.

\section{AicE-Bs2016Edinburgh Theme: Adapted and adaptable environments}

As humans, we strive for a better environment for living in the present, and for the existence of future generations. We learn to negotiate, adapt or seek to counter environments that may be damaged or no longer needed for their original intention or purpose, by modifying their use in creative ways. We may simply allow the environment to lead in this process. AicE-Bs 2016 Edinburgh invites discussions, exchange of ideas and debates on how through our diverse cultures, we carry on with our daily lives, communicating, working, learning, healthy ageing - all, conforming or modifying the environment, in response to the ever-changing environment, and vice versa....

AicE-Bs2016Edinburgh invites both conceptual and empirical papers which address those issues in relation to the following environment (though not exhaustive):-

Children's Environment; Commercial/Retail/Services Environment; Communications \& Social Media Environment; Community Environment / Social Psychology; Construction Environment; Inclusive Environment; Educational/Learning Environment; Elderly Environment; General Psychology; Healing/Healthcare Environment; Hospitality/Tourism Environment; Landscaping Environment; Legal Matters; Leisure/Recreational/Sports Environment; Local Cultural/Heritage Environment (Food included); Natural Environment; Residential Environment; Rural Environment / Rural Psychology; Technology-related Environment; Transportation/Traveling Environment; Urban Environment / Urban Psychology; Workplace Environment; etc. 


\section{Editorial Team}

\section{Editor-In-Chief}

Mohamed Yusoff Abbas, Prof., Dr.

President, Association of Malaysian Environment-Behaviour Researchers (AMER).

President, Association of Behavioural Researchers on Asians (ABRA).

Head, Centre for Environment Behaviour Studies (cE-Bs), Universiti Teknologi MARA, Malaysia

myusoff801@salam.uitm.edu.my, cebsuitm@gmail.com

Assistant Editor-In-Chief

Sharifah Khalizah Syed Othman Thani

\section{Associate Editors \\ EGYPT:}

Rasha Mahmoud Ali El-Zeiny, Assoc. Prof., Dr., Menia University, Menia, Egypt. rasha_elzeiny@yahoo.com

INDIA:

Smita Khan, Assoc. Prof., Dr., Ar. Visvesvaraya National Institute of Technology, Najpur, India.smitakhan@gmail.com INDONESIA:

Juneman Abraham, Bina Nusantara University, Jakarta, Indonesia. juneman@gmail.com

IRAN:

Mona Bisadi, Dr. Iran University of Science \& Technology, Tehran, Iran. bisadi.mona@gmail.com

TAIWAN:

Shenglin Elijah Chang, Prof., Dr. National Taiwan University, Taipei, Taiwan. shenglinchang@gmail.com

TURKEY:

Ebru Cubukcu, Prof., Dr. Dokuz Eylul University, Turkey. ebru.cubukcu@gmail.com

\section{Editorial (Advisory \& Review) Board}

Abdul Hadi Nawawi, Prof., Dr. Universiti Teknologi MARA, Malaysia. hadinawawi@yahoo.com

Aldrin Abdullah, Prof., Dr. Universiti Sains Malaysia, Malaysia. aldrin.usm@gmail.com

Aleya Abdel Hadi, Emer. Prof., Dr. Modern Sciences \& Arts University, October City, Egypt. profaleyaabdelhadi@gmail.com

Anuar Talib, Assoc. Prof., Dr. Universiti Teknologi MARA, Malaysia. anuarfaqir@gmail.com

Ashraf M. Salama, Prof., Dr. University of Strathclyde, Glasgow, United Kingdom. asalama@gmail.com

Babatunde E. Jaiyeoba, Assoc. Prof., Dr. ObafemiAwolowo University, Ile-Ife, Nigeria, Nigeria. tundejaiyeoba@yahoo.co.uk

Christopher Peter Spencer, Emer. Prof., Dr. The University of Sheffield, United Kingdom. c.p.spencer@sheffield.ac.uk

Cigdem Canbay Turkyilmaz, Assoc. Prof., Dr. Yildiz Technical University, Turkey. cigdemcanbay@gmail.com

Darussalam Abu Bakar, Prof., Dr. Universiti Teknologi MARA, Malaysia. darussal@salam.uitm.edu.my

Dasimah Omar, Prof., Dr. Universiti Teknologi MARA, Malaysia. dasimaho@yahoo.com

David Dernie, Prof., Dr. University of Westminster, United Kingdom. D.Dernie@westminster.ac.uk

David Robert Osborne, Graphia International Limited, Hong Kong. dro@graphiabrands.com

Ebru Cubukcu, Prof., Dr. Dokuz Eylul University, Turkey. ebru.cubukcu@gmail.com

Edinéa Alcântara, Dr. Federal University of Pernambuco, Brazil. edinealcantara@gmail.com

Edward Andrew Edgerton, Dr. West of Scotland University, United Kingdom. Edward.Edgerton@uws.ac.uk

Elizabeth Grant, Dr. The University of Adelaide, Australia. elizabeth.grant@adelaide.edu.au

Ellen Matthies, Prof., Dr., Otto von Guericke Universitat Magdeburg, Germany. ellen.matthies@ovgu.de

Emrah Turkyilmaz, Dr. Istanbul Kultur University, Turkey. emrahturk@gmail.com

Faridah Ismail, Assoc. Prof., Dr. Universiti Teknologi MARA, Malaysia. farid346@salam.uitm.edu.my

Filiz Çelik, Asst. Prof., Dr. Selcuk University, Konya, Turkey. filiz@selcuk.edu.tr

Hazlina Hamdan, Assoc. Prof., Dr. Universiti Teknologi MARA, Malaysia. hazlina2020@yahoo.com

Hazreena Hussein, Assoc. Prof., Dr. University Malaya, Malaysia. reenalambina@um.edu.my

Heng Zhang, Prof., Dr. National Cheng Kung University, Taiwan, Province of China. heng7970@gmail.com

Himasari Hanan, Dr., Ir. Institut Teknologi Bandung, Bandung, Indonesia. himahanan@gmail.com

Ismail Said, Prof., Dr. Universiti Teknologi Malaysia, Malaysia. ismailbinsaid@gmail.com

Ismail Samsuddin, Prof., Dr. Universiti Teknologi MARA Perak, Malaysia. ismai587@perak.uitm.edu.my

Iwan Sudradjat, Institut Teknologi Bandung, Bandung, Indonesia. iwansudr@gmail.com

Jamalunlaili Abdullah, Assoc. Prof., Dr. Universiti Teknologi MARA, Malaysia. bota65@yahoo.com 
Joongseok Joseph Ryu, Prof., Dr. Chung-Ang University, Seoul, Korea. joseph.j.ryu@gmail.com Jin-Yung Wu, Asst. Prof., Dr. National Taiwan University, Taipei, Taiwan, Province of China. jinyungwu@gmail.com Juneman Abraham, ABRA, Bina Nusantara University, Jakarta, Indonesia. juneman@gmail.com Kate Bishop, Dr. University of New South Wales, Sydney, Australia. kbishop@bigpond.com Lobna Abdel Aziz Ahmed, Assoc. Prof., Dr. Menia University, Menia, Egypt. Arch.Lobna@gmail.com Mariam Jamaluddin, Assoc. Prof., Dr. Universiti Teknologi MARA, Malaysia. marja67@gmail.com Masahiro Shirotsuki, Dr. Nagoya University, Japan. mshiro@nufs.ac.jp

Masran Saruwono, Assoc. Prof., Dr. Universiti Teknologi MARA, Malaysia. mbsaruwono@yahoo.co.uk Mazlina Mansor, Asst. Prof., Dr. International Islamic University, Malaysia. mazlina.mansor@gmail.com Mei Lim, Dr. University of South Australia, Australia. Mei.Lim@unisa.edu.au Mert Cubukcu, Prof., Dr. Dokuz Eylul University, Izmir, Turkey. mert.cubukcu@gmail.com Mohammad Arif Kamal, Asst. Prof., Dr. Aligarh Muslim University, India. architectarif@gmail.com Mohd. Sabrizaa Abd Rashid, Assoc. Prof., Dr. Universiti Teknologi MARA Perak, Malaysia. mohds637@perak.uitm.edu.my Mona Bisadi, Dr. Iran University of Science \& Technology, Tehran, Iran. bisadi.mona@gmail.com Nicholas Kathijotes, Prof., Dr. Cyprus University of Technology, Cyprus. nkathijotes@gmail.com Nisha Fernando, Prof., Dr. University of Wisconsin, United States of America. Nisha.Fernando@uwsp.edu Nor Haslina Jaafar, Dr. Universiti Kebangsaan Malaysia, Malaysia. mellina.inamel@gmail.com Nor Zalina Harun, Assoc. Prof., Dr. International Islamic University Malaysia, Malaysia. nzalina76@gmail.com Noor Hanita Abdul Majid, Assoc. Prof., Dr. International Islamic University Malaysia, Malaysia. noorhanita@gmail.com Norhati Ibrahim, Assoc. Prof., Dr. Universiti Teknologi MARA, Malaysia. norhati102@yahoo.com Noriah Othman, Dr. Universiti Teknologi MARA, Malaysia. noriaho@yahoo.com Norsidah Ujang, Assoc. Prof., Dr. Universiti Putra Malaysia, Malaysia. norsidah21@gmail.com Nurlisa Ginting, Assoc. Prof., Dr. Universiti Sumatera Utara, Medan, Indonesia. nurlisa.ginting@gmail.com Osman Mohd Tahir, Assoc. Prof., Dr. Universiti Putra Malaysia, Malaysia. osman_mtahir@yahoo.com Paramita Atmodiwirjo, Prof., Dr. Universitas Indonesia, Indonesia. mitayandi@gmail.com Prabu Wardono, Dr. Institut Teknologi Bandung, Bandung, Indonesia. pwardono@yahoo.com Rasha Mahmoud Ali El-Zeiny, Assoc. Prof., Dr. Menia University, Menia, Egypt. rasha_elzeiny@yahoo.com Ranjith Dayaratne, Assoc. Prof., Dr. University of Bahrain, Bahrain. ranjith.dayaratne@gmail.com Robert W. Marans, Emer. Prof., Dr. University of Michigan, Michigan, United States of America. marans@umich.edu Rugayah Gy Hashim, Prof., Dr. Universiti Teknologi MARA, Malaysia. hajahgy@gmail.com Sabarinah Sh. Ahmad, Prof., Dr. Universiti Teknologi MARA, Malaysia. sabrin63@gmail.com Saripah Abdul Latif, Universiti Teknologi MARA Kelantan, Malaysia. saripah5998@gmail.com Shenglin Elijah Chang, Prof., Dr. National Taiwan University, Taipei, Taiwan. shenglinchang@gmail.com Siriwan Silapacharanan, Emer. Prof., Dr. Chulalongkorn University, Bangkok, Thailand. siriwansv@gmail.com Sitthiporn Piromruen, Assoc. Prof., Dr. Silpakorn University, Bangkok, Thailand. sitthip128@yahoo.com Siti Rukayah, Dr. Diponegoro University, Semarang, Indonesia. tututrsiti@yahoo.com Siu Oi Ling, Prof., Dr. Lingnan University, Hong Kong. siuol@In.edu.hk Smita Khan, Assoc. Prof., Dr. Visvesvaraya National Institute of Technology, Najpur, India. smitakhan@gmail.com Supagtra Suthasupa, Asst. Prof., Dr. Silpakorn University, Bangkok, Thailand. supakoy@yahoo.com Uday Jain, Emer. Prof., Dr. Mahila Chetna Manch, Shivaji, Nagar, Bhopal, India. jainuday1941@gmail.com Wan Hashimah Wan Ismail, Dr. Universiti Teknologi Malaysia, Malaysia. wan7137shima@gmail.com Wannasilapa Peerapun, Prof., Dr. Chulalongkorn University, Bangkok, Thailand. Wannasilpa.P@chula.ac.th Zehra Öngül, Asst. Prof. Eastern Mediterranean University, Famagusta, Turkey. zehra.ongul@gmail.com 


\section{Full Paper List}

No.

DOI

Titles / Authors / Affiliations / Emails

Pages

Commercial / Retail / Services Environment

Centre of Studies for Real Estate Management, Faculty of Architecture Planning \& Surveying, Universiti Teknologi MARA, 40450 Shah Alam, Selangor ${ }^{\star}$,Centre of Studies for Real Estate Management, Faculty of Architecture Planning \& Surveying, Universiti Teknologi MARA, 40450 Shah Alam, Selangor, Centre of Studies for Real Estate Management, Faculty of Architecture Planning \& Surveying, Universiti Teknologi MARA, 40450 Shah Alam, Selangor, zarit928@salam.uitm.edu.my

Management \& Science University, (MSU) Malaysia, Shah Alam, Malaysia. ${ }^{*}$ ,Center for Postgraduate and Professional Studies, Faculty Business of Management, Universiti Teknologi MARA, Shah Alam,Malaysia., Center for Postgraduate and Professional Studies, Faculty Business of Management, Universiti Teknologi MARA, Shah Alam,Malaysia

all_aina@hotmail.com

\section{Community Environment / Social Psychology}

A Structural Equation Model of Improvement in Quality of Life in a

Department of Urban and Regional Planning, Faculty of Built Environment, Universiti Teknologi Malaysia, 81310, Johor Bahru, Malaysia* ,Department of Urban and Regional Planning, Faculty of Built Environment, Universiti Teknologi Malaysia, 81310, Johor Bahru, Malaysia, Centre for Innovative Planning and Development, Faculty of Built Environment, Universiti Teknologi Malaysia, 81310, Johor Bahru, Malaysia, Centre for Innovative Planning and Development, Faculty of Built Environment, Universiti Teknologi Malaysia, 81310, Johor Bahru, Malaysia zmuhammed1140@gmail.com

\section{Construction Environment}

Insights into the adoption of green construction in Malaysia: The drivers and challenges

Asmah Alia Mohamad Bohari ${ }^{*}$, Martin Skitmore, Bo Xia

School of Civil Engineering and Built Environment, Queensland University of Technology, Brisbane, Australia*. Faculty of Architecture, Planning and Surveying, Universiti Teknologi MARA Sarawak, Kota Samarahan, Sarawak, Malaysia* ,School of Civil Engineering and Built Environment, Queensland University of Technology, Brisbane, Australia, School of Civil Engineering and Built Environment, Queensland University of Technology, Brisbane, Australia. alyiaboh@gmail.com

\section{Educational / Learning Environment

Norashikin Hussein*, Ainie Hairiainie Aluwi, Fauziah Noordin, Noormala Amir Ishak Faculty of Business and Management, Universiti Teknologi MARA, Malaysia* ,Faculty of Business and Management, Universiti Teknologi MARA, Malaysia, Centre for Postgraduate and Professional Studies, Universiti Teknologi MARA, Arsyad Ayub Graduate Business School, Universiti Teknologi MARA, Malaysia shikin6320@salam.uitm.edu.my Universiti Teknologi MARA, 40450 Shah Alam, Malaysia. School of Architecture and Landscape Architecture, Edinburgh College of Art, The University of Edinburgh, Scotland, United Kingdom* School of Architecture and Landscape Architecture, Edinburgh College of Art, The University of Edinburgh, Scotland, United Kingdom.

nikfarhanah.azhari@gmail.com 


\section{Health / Healing Environment}

P8

https://doi.org/10.21834/e-bpj.v1i4.173

\section{Local Heritage Environment \\ P10 https://doi.org/10.21834/e-bpj.v1i4.132}

P11 https://doi.org/10.21834/e-bpj.v1i4.91

\section{Residential Environment

\section{Technology-related Environment P15}

Characteristics of Autism Center in Malaysia Amily Fikry*, Hamizah Hassan Centre of Postgraduate and Professional Studies, Faculty of Business Management, Universiti Teknologi MARA (UiTM) Shah Alam, 40000 Shah Alam, Selangor, Malaysia*, Centre of Postgraduate and Professional Studies, Faculty of Business Management, Universiti Teknologi MARA (UiTM) Shah Alam, 40000 Shah Alam, Selangor, Malaysia, amilyfikry@yahoo.com

Facilities Management AUDIT in Managing Healing Facilities in Public Health Care Built Environment: User Satisfaction Viewpoint

Ahmad Ezanee Hashim*, Siti Aida Samikon, Mohamad Sufian HasimMahyudin Mahmood

Faculty of Architecture, Planning and Surveying, Universiti Teknologi MARA (UiTM), 40450 Shah Alam, Selangor, Malaysia. ${ }^{*}$,Faculty of Science, Technology, Engineering and Mathematics, International University of Malaya-Wales (IUMW), 50480 Kuala Lumpur, Malaysia. ezanee54@gmail.com

Heritage Conservation Management in Egypt: The balance between heritage conservation and real-estate development in Alexandria Dina Mamdouh Nassar*

Architecture Engineering Department, Faculty of Engineering, Alexandria University*

dnassararch@yahoo.com

Morphology of Traditional City Center in Semarang: Towards Adaptive reuse in urban heritage

R. Siti Rukayah*, Dhanang Respati Puguh, Endang Sri Susilo Setiyorini

Master Program of Architecture, Engineering Faculty, Universitas Diponegoro* ,Department of History, Culture Faculty, Universitas Diponegoro, Marine Science Faculty, Universitas Diponegoro, Indonesia tututrsiti@yahoo.com

Revitalization of Ottoman Industrial Heritage in Kemeraltı and Izmir History Project

Yakup Egercioglu, Çağlayan Deniz Kaplan

Department of City and Regional Planning, Faculty of Engineering and

Architecture, Izmir Katip Çelebi University, Izmir, Turkey, Directorate of Historical

Environment and Cultural Properties, Izmir Metropolitan Municipality, Izmir,

Turkey

Yakup Egercioglu yakupegercioglu@gmail.com

Traditional Streetscape Adaptability: Urban gentrification and endurance of business

Arif Budi Sholihah", Tim Heath

Dept of Architecture, Islamic University of Indonesia, Yogyakarta* ,Dept of Architecture and Built Environment, University of Nottingham, UK,

arif.sholihah@gmail.com

Strategies to Improve the Implementation of Planning Mechanisms for Urban Housing Development in Selangor Hamizah Yakob*, Fatimah Yusof, Hazlina Hamdan

Centre of Graduate Studies, FSPU, UITM, Malaysia*, Centre of Studies for Town and Regional Planning, FSPU, UITM, Malaysia

hamizah1204@gmail.com

Intention to Revisit and to Purchase: The effects of user's attitude in game advertising

Zuhal Hussein*, Nabsiah Abd Wahid 


\section{Travel / Transportation Environment P16 https://doi.org/10.21834/e-bpj.v1i4.137}

https://doi.org/10.21834/e-bpj.v1i4.383

https://doi.org/10.21834/e-bpj.v1i4.166

https://doi.org/10.21834/e-bpj.v1i4.138

https://doi.org/10.21834/e-bpj.v1i4.384

https://doi.org/10.21834/e-bpj.v1i4.95
Faculty of Business Management, UniversitiTeknologi MARA, Kota Bharu Campus, Wisma KUB, Jalan Sultan Ibrahim, 15050, Kota Bharu, Kelantan* ,Graduate School of Business, Universiti Sains Malaysia, 11800, USM, Penang, zuhalhk@yahoo.com

\section{Are Euclidean Distance and Network Distance Related ?}

K. Mert Cubukcu*, Hatcha Taha

City and Regional Planning, Architechture, Dokuz Eylul University, Turkey*, City and Regional Planning, Architechture, Dokuz Eylul University, Algeria, mert.cubukcu@gmail.com

\section{Urban Environment / Urban Psychology}

P17 https://doi.org/10.21834/e-bpj.v1i4.382

Adaptable Environment: Analysis on form and content of the Local Plan in Selangor, Malaysia

Suhaini Mohamed Yusoff*, Fatimah Yusof, Ahmad Fuzi Arshad

Department of Town and Regional Planning, Faculty of Architecture Planning and Surveying, University Technology MARA, Shah Alam, 40450 Malaysia* suhainiyusoff@gmail.com

Assessment of Adaptable Urban Environment for Public Art Integration through Observation Study: Johor Bahru City Centre

Muhammad Falihin Jasmi*, Nik Hanita Nik Mohamad

Institute of Graduate Studies, Faculty of Architecture, Planning and Surveying, Universiti Teknologi MARA (UiTM) Shah Alam, Selangor, Malaysia* ,Centre of Studies in Landscape Architecture, Faculty of Architecture, Planning and Surveying, Universiti Teknologi MARA (UiTM) Puncak Alam, Selangor, Malaysia. falihinjasmi@gmail.com

How Does Street Vending Contribute to Walkability? A report on a study in Yuncheng, China

Ziwen Sun*

Edinburgh School of Architecture and Landscape Architecture, The University of Edinburgh, UK*

Ziwen.Sun@ed.ac.uk

Physical Environmental Quality and Urban Design Education in Palestine and Turkey

Ebru Cubukcu*, Fahmi Salameh

Dokuz Eylül University „Dokuz Eylül University, Turkey

ebru.cubukcu@deu.edu.tr

Solar Radiation and Urban Wind Effect on Urban Canyon in Hot, Humid Regions

Lin Yola*, Ho Chin Siong

Department of Built Environment, Universiti Teknologi Malaysia and UCSI University, Malaysia* ,Department of Built Environment, Universiti Teknologi Malaysia, Malaysia

lin_yo_la@yahoo.com

Urban Challenge Meets Hidden Potentials: Sustainable Development of ElMax Fishermen Village in Alexandria, Egypt

Jenny Ernawati ${ }^{*}$, Satya Aditama, SurjonoBeta Suryokusumo

Department of Architecture, Faculty of Engineering, University of Brawijaya, Indonesia* ,Department of Architecture, Faculty of Engineering, University of Brawijaya, Indonesia, Department of Architecture, Faculty of Engineering, University of Brawijaya, Indonesia, Department of Architecture, Faculty of Engineering, University of Brawijaya, Indonesia

jenny.ernawati@fulbrightmail.org

\footnotetext{
Urban Design Qualities Related Walkability in a Commercial Neighbourhood

Dina Mamdouh Nassar*, Marwa Kamel El-Sayed

Architecture Engineering Department, Faculty of Engineering, Alexandria University ${ }^{*}$,Architecture Engineering Department, Faculty of Engineering, Pharos University in Alexandria, Egypt.

dnassararch@yahoo.com
}

\section{Working Environment}

\section{Minimum Wage and Productivit
Malaysian hotel employees} Idaya Husna Mohd*

Centre for Management \& Administrative Studies (CFMAS), Faculty of Business and Management Universiti Teknologi MARA, 42300. Puncak Alam, Malaysia* idayahusnamohd@gmail.com 
.

Department of Multidisciplinary Design Research, Faculty of Architecture, King Mongkut's Institute of Technology Ladkrabang , Bangkok 10520, Thailand* ,School of Psychology, Faculty of Health and Medical Sciences, University of Surrey, Guildford, Surrey GU2 7XH, United Kingdom, Department of Interior Architecture, Faculty of Architecture, King Mongkut's Institute of Technology Ladkrabang, Bangkok 10520, Thailand nattha@msn.com

Muhamad Khalii Omar*, Azzarina Zakaria

Faculty of Business and Management, Universiti Teknologi MARA, Malaysia khalil.omar@salam.uitm.edu.my

Manifestation of work-life balance in the Malaysian banking workforce:

Transformational leadership the potent enabler

Azzarina Zakaria*, Muhamad Khalil Omar

Faculty of Business and Management, Universiti Teknologi MARA, Shah Alam, Selangor, Malaysia*,Faculty of Business and Management, Universiti Teknologi MARA, Puncak Alam, Selangor, Malaysia azzarina@salam.uitm.edu.my 


\section{Past and Future Conferences}

1nCEBS2009ShahAlam, Malaysia, 14-15 Nov 2009

1st AcE-Bs2010Kuching, Malaysia, 07-08 Jul 2010

$1^{\text {st }}$ AicE-Bs2010Kuching, Malaysia, 07-09 Dec 2010

$2^{\text {nd }}$ AcE-Bs2011Bandung, Indonesia, 15-17 Jun 2011

$2^{\text {nd }}$ AicE-Bs2011Famagusta, North Cyprus, 07-09 Dec 2011

$3^{\text {rd }}$ AcE-Bs2012Bangkok, Thailand, 16-18 Jul 2012

$3^{\text {rd }}$ AicE-Bs2012Cairo, Egypt, 31 Oct-02 Nov 2012

$4^{\text {th }}$ AcE-Bs2013Hanoi, Vietnam, 19-22 Mar 2013

1st AicQoL2013Langkawi, Malaysia, 06-08 Apr 2013

$4^{\text {th }}$ AicE-Bs2013London, United Kingdom, 04-06 Sep 2013

$2^{\text {nd }}$ AicQoL2014Kota Kinabalu, Sabah, Malaysia, 04-05 Jan 2014

$5^{\text {th }}$ AicE-Bs2014Berlin, Germany, 24 - 26 Feb 2014

$5^{\text {th }}$ AcE-Bs2014Seoul, South Korea, 25-27 Aug 2014

1st AQoL2014lstanbul, Turkey, 26 - 28 Dec 2014

$6^{\text {th }}$ AcE-Bs2015Tehran, Iran, 21 - 23 Feb 2015

3rd AicQoL2015Jakarta, Indonesia, 25 - 27 Apr 2015

$6^{\text {th }}$ AicE-Bs2015Bacelona, Spain, 31 Aug - 05 Sep 2015

$2^{\text {nd }}$ AQoL2015lzmir, Turkey, 09-13 Dec 2015

$4^{\text {th }}$ AicQoL2016Medan, Indonesia, 25 - 27 Feb 2016

$7^{\text {th }}$ AcE-Bs2016Taipei, Taiwan, 09-10 Apr 2016

$7^{\text {th }}$ AicE-Bs2016Edinburgh, Scotland, UK, 27-30 Jul 2016

$5^{\text {th }}$ AicQoL2017Bangkok, Thailand, 25-27Feb 2017

3rd AQoL2017Kuching, Malaysia, 14-16 Oct 2017

6th AicQoL2018Perhentianlsland, Malaysia, 03-04 March 2018

$8^{\text {th }}$ AicE-Bs2018Sheffield, UK, 14-15 Jul 2018

4thAQoL2018Istanbul, Turkey, 03-06 Nov 2018

7th AicQoL2019Bali, Indonesia, 23-24 Feb 2019 